\title{
living on; not getting better
}

Margrit Shildrick

\section{Linköping University Post Print}

\section{Tweet}

N.B.: When citing this work, cite the original article.

Original Publication:

Margrit Shildrick , living on; not getting better, 2015, Feminist review (Print), 111, 10-24.

http://dx.doi.org/10.1057/fr.2015.22

Copyright: Palgrave Macmillan

http://www.palgrave-journals.com/pal/index.html

Postprint available at: Linköping University Electronic Press

http://urn.kb.se/resolve?urn=urn:nbn:se:liu:diva-123145 


\title{
00 | living on; not getting better
}

\author{
Margrit Shildrick
}

\section{abstract}

The contemporary emergence of the concept 'debility', which pertains to a broad swathe of humanity whose ordinary lives simply persist without ever getting better, shares a time span with an acute critique of neoliberal biopolitics. Where capital has historically relied on a population that through its labour necessarily becomes debilitated, the newer model of understanding references the intrinsic profitability of debility itself. The two dimensions overlap and co-exist, but what I shall pursue here are the implications of recognising that, at the most fundamental level, it is in the interests of neo-liberalism to produce and sustain bodies as debilitated and therefore susceptible to a range of market commodities that hold out the promise of therapeutic interventions into the relative failures of physical, cognitive and affective embodiment. In previous work (Shildrick), I have argued strongly for the inherent vulnerability of all bodies, but in considering here a more overtly politicised context, it becomes possible to readdress the questions posed by Jasbir Puar: "which bodies are made to pay for "progress"? Which debilitated bodies can be reinvigorated for neoliberalism, and which cannot?' (p. 153). And at the present moment, writing at a time of imposed austerity, I would add, what, if anything, is lost in the deployment of the term debility instead of disability?

\section{keywords}

debility; neoliberalism; biopolitics 
The emergence of the concept 'debility', as pertaining not just to those weakened by illness, over-exertion or disability, as dictionary definitions still insist, but to a broad swathe of humanity whose ordinary lives simply persist without ever getting better, shares a time span with an acute critique of neo-liberal biopolitics. Where capital has historically relied on a population that through its labour necessarily becomes debilitated, the newer model of understanding references the intrinsic profitability of debility itself. As Puar (2012, p. 153) succinctly puts it,'In neoliberal, biomedical, and biotechnological terms, the body is always debilitated in relation to its ever-expanding potentiality'. The two dimensions overlap and co-exist, but what I shall pursue here are the implications of recognising that, at the most fundamental level, it is in the interests of neo-liberalism to produce and sustain bodies as debilitated and therefore susceptible to a range of market commodities that hold out the promise of therapeutic interventions into the relative failures of physical, cognitive and affective embodiment. In previous work (Shildrick, 2002, 2009), I have argued strongly for the inherent vulnerability of all bodies, but in considering here a more overtly politicised context, it becomes possible to readdress the questions posed by Puar (2012, p. 153): "which bodies are made to pay for "progress"? Which debilitated bodies can be reinvigorated for neoliberalism, and which cannot?' And at the present moment, writing at a time of imposed austerity, I would add, what, if anything, is lost in the deployment of the term debility instead of disability?

My focus on the problematic in this paper will frequently reference the situation in the United Kingdom, but that is not to overlook the global dimensions of debility and the intersections between neo-liberalism, race and poverty, for example. Certainly the thinking through of debility must seek to counter the centrality of relatively privileged white bodies in disability discourse, but at the same time I am concerned to avoid a knee-jerk assertion of inclusion that risks simplifying distinctions and collapses specificity. The danger lies in appropriating the critique of other oppressions by covering over the specific historical circumstances that underpin and sustain them. The operation of transnational capitalism, for example, demands a highly nuanced consideration of historical materialism, such as that offered by Nirmala Erevelles, who worries that the conditions of possibility being opened up by critical disability studies in particular will obfuscate any sense of structural limits. As she puts it:

... there is no respite from the harsh living conditions of poverty nor from the exploitative social relations of production and consumption or from the historical continuities of (neo)-colonial wars and a (neo)imperialist political economy-all of which produce, propagate, and proliferate disability while simultaneously rendering disabled people completely invisible. (Erevelles, 2014, np)

That much should always be evident but it cannot mark a constraint on thinking otherwise, on pursuing what may turn out to be hopelessly utopian, but may also multiply possibilities of transformation. The two approaches represent different stagings of the same problematic and should not be seen as contradictory. Erevelles is undoubtedly right to remind us of the global differentials of power, but is herself also concerned to reflect on how we might negotiate the interface between apparently conflicting methodologies. Each element requires thorough attention that is beyond the intended scope of this paper and I do no more than provide signposts.

Before considering the contemporary realities in which the concept of debility seems to offer an analytic take-off point, it should be stressed that the strange ambiguities of the situation we all face-whether embodied as disabled or not-are by no means peculiar to neo-liberalism. In the current politicoeconomic climate, to be debilitated does not place one outside societal or even individual norms; there is 
no bounded category to be othered. Similarly, even within the rigid binaries associated with disability, the paradoxical category of the able-disabled (Overboe, 1999; Titchkosky, 2003; Mitchell, 2014) has a long history in which certain people-and usually those with physical as opposed to cognitive disabilitieswere relatively easily assimilated into the mainstream norms of society. In his book A History of Disability, Stiker (1999), for instance, deconstructs the practices of rehabilitation, in the context of early twentiethcentury France, to show how the disabled body moved from being the object of 'exclusion and surveillance' that was subjected to othering, to being situated within 'regimes of recovery and assistance' (p. 114). Whatever the stated intentions of rehabilitation, which have generally been figured as beneficent, Stiker is insistent that the reclaimed and normalised body served to dampen down normative anxiety about the ontological and epistemological insult of extra-ordinary embodiment. As he notes:

rehabilitation marks the appearance of a culture that attempts to complete the act of identification, of making identical. This act will cause the disabled to disappear and with them all that is lacking, in order to assimilate them, drown them, dissolve them in the greater and single social whole. (Stiker, 1999, p. 128)

This kind of limited and effectively exclusionary inclusion has been welcomed not only by the generality but also by many strands of disability rights activism, where the attainment of similar rights to other citizenseven at the cost of both further marking down those left behind and taking on a certain invisibility oneself - has been unproblematically celebrated. This is particularly true in the global North where, as Soldatic and Grech (2014) point out, the demand for social justice is secondary to claims on full citizenship (see also Shildrick, 2012). Their concern is that the disabilities caused by war, poverty and the rigours of unrestrained capitalist exploitation - which is most prevalent in the global South-will be disregarded. I am not suggesting that the struggle for rights is misplaced, but that it must always be accompanied by a rigorous critique and modes of self-reflection that interrogate the limitations and consequences of a political process that cements new divisions. That critique is too often absent, as in one well-promoted journal of the last thirty years called unapologetically MAINSTREAM: Magazine of the Able-Disabled. The insistent message is that with sufficient personal commitment to self-management, disabled people may be regarded as enjoying the same opportunities as everyone else.

A similar finessing of the edges of blatant discrimination is evident in many situations where people with disabilities are seen to overcome their nominal debility to the extent of satisfying or even exceeding societal norms. At one end of the spectrum are those who can more or less 'pass', those able-disabled who, as Carrie Sandahl sardonically reflects, 'clean up nice for company-those whose appearances and behaviors stray least from the norm, and who require few or no accommodations to participate in mainstream culture, including as wage earners' (in McRuer and Johnson, 2014, p. 157). Even in more challenging cases where non-normative embodiment is fully evident, the individual triumphs of what disability critique scornfully calls supercrips can settle mainstream anxieties about all-too-evident difference. We have all become familiar, for example, with the spectacle of flourishing Paralympian competitors being feted in the popular media as the standard towards which all disabled people couldand, by implication, should - aspire (Shildrick, 2015,-fortheral pleasure it so clearly brings, there is something to celebrate in any successful negotiation of the structures of prejudice. The dilemma for disability theorists at least is how to accept the necessity of compromise while maintaining a vigorous critique aimed at the dominant system rather than at the individuals involved. It is, to recall Spivak's (1989) much-quoted understanding of deconstruction, a critique of 
something useful, a critique of something we cannot do without. The need for critique is interminable for, lest we forget, the irony is that the acclamation of the achievements of disabled athletes at the London Paralympics has been coincident with the ongoing programme undertaken by ATOS - the UK governmentappointed operative - to ruthlessly weed out and exclude from benefits those deemed undeserving, lazy, beyond repair. ${ }^{1}$ These surely are the debilitated bodies that are marked as beyond reinvigoration for neo-liberalism.

What does it mean then to move beyond simple binaries to say that debility is an inherent facet of the sociality in general? Certainly it is not the same as the existing notion that we are all vulnerable to bodily and/or mental breakdown at some point in our lives. ${ }^{2}$ This has often been taken up in conventional disability studies through the idea that those who consider themselves non-disabled are in fact no more than temporarily able-bodied $(T A B){ }^{3}$ The argument, which is firmly grounded in the reality of most people's life courses, is that not only are we all at risk of unexpected accident and disease that might precipitate disability, but that as we age our bodies inevitably begin to fall away from a normative standard of mental and physical capacity. The observation that everyone is TAB is fairly banal in its simple form, but it has been used to argue for a certain commonality, a breaking down of the binary of disabled/ non-disabled that contests the hierarchy of value that has been so injurious to those with disabilities. Until quite recently, the term debility did not even go this far, and it has been used conventionally and almost exclusively in the medical model of disability to describe a set of pathologised capacities and affects centred on the individual. In critical disability studies and cultural critique more generally, however, the concept of debility has become a political tool in the task of understanding and challenging the ideological and economic models of neo-liberalism. As Jasbir Puar puts it:

The political mandate behind such ... a move from disability to debility ... would not be to disavow the crucial political gains enabled by disability activists globally, but to invite a deconstruction of what ability and capacity mean, affective and otherwise, and to push for a broader politics of debility that destabilizes the seamless production of abled-bodies in relation to disability. (Puar, 2012, p. 166)

In effect, debility no longer references non-normative bodies with signally deficit capacities but shifts to describe 'fetishizations of minor, yet prolific, incapacitations' (Mitchell and Snyder, 2015, fortheoming). Both Puar and Mitchell, nonetheless, do still revert on occasion to wanting to make some distinction between capacity and deficiency with some and not others permanently unable to access full capacitation. Such a move may be both politically and pragmatically more acceptable, but as I understand it, the theorisation of debility offers a more complex perspective than the one they fall back on: that no one escapes the mark of debility, even though its effect is highly differentiated. And debility is ubiquitous precisely because neo-liberalism depends on it. Whether that formulation is useful for a disability politics is yet to be decided.

What does seem clear is that the concept of debility is working in at least two registers that have little to do with frailty - the other privileged term of this special issue-as such. It was surprising to see the conjunction of the two terms - frailty and debility-in the call for papers as it seems to suggest

\footnotetext{
${ }^{1}$ See Bambra and Smith (2010), Garthwaite (2011) and Soldatic and Meekosha (2012). I will return to this point later.

${ }^{2}$ See Ecclestone and Goodley (2014) for further discussion of this point.

${ }^{3}$ Despite its ubiquity in disability circles, the designation TAB has been challenged for its lack of nuance, with the term CA (currently abled) offered as an alternative. For an interesting discussion, see the guestpost by Edison and Notkin (2010) and the responses to it on the website Forward (Feminists with Disabilities).
} 
something coterminous, and I am not yet aware of work that entirely disrupts the negative connotations of frailty as implying at least 'already on the way to failure'. One might well argue that frailty remains better grounded in lived experience, that it allows us to face the differences of ageing or ill-health head on. Stripped of its other haunting references, my own title for this paper, 'Living on; not getting better', might well describe a condition of frailty, but it is debility that opens up more expansive dimensions. In the first instance, debility-like vulnerability-seems to me to be an existential state that need not have any particular material referent in the body. In its current usage in critical cultural theory, it indicates that living on is always measured against an impossible scene of fulfilment, a fantasy of full capacity that is ever beyond reach. It invokes both an underlying ontological anxiety and a futile desire to resolve that anxiety through strategies of self-realisation directed towards happiness-a privileged trope of western neo-liberalism (Ferguson, 2007; Ahmed, 2010; Kingfisher, 2013) —and, more generally, well-being. To be debilitated - to never reach the putative security of corporeal, affective and cognitive standards of flourishing- st the condition of life. I am not thinking here of the horizons of aspiration, so beloved by poststructuruist-inflected theorists such as myself, for those are potentially transformative, but more of the cruel optimism of which Lauren Berlant writes. As she explains, 'A cruel optimistic relation exists when the objects of optimism are blockages to the achievement of the desire for which they stand in' (Berlant and Prosser, 2011, p. 182). What matters is that the promise of getting better is sufficiently convincing to motivate behaviours that not only will fail to arrive at the anticipated goal but may even contribute to the impossibility of such an arrival. It is in this sense that the ontological dimension of debility segues into its second register, that of its political and socioeconomic utility.

This too works on two intersecting levels. On the one hand, the structural organisation of social and economic relations under capitalism produces debility as its by-product in the very material sense of exhausted bodies and minds. The analysis of labour as such needs no further elaboration here, except to stress once again the differential impact on the rich and poor; those of the global North and global South; people who are non-disabled and those who are disabled; men and women; black and white; young and old, and so on through every register of inequity. Put bluntly in a local context, "work is one of the major contributors to all the UK's major killers - cancer, heart disease and obstructive lung disease. The same goes for the major causes of long term sick leave, including mental illness and back pain' (Ferguson, 2007, np). To a greater or lesser extent bodies are literally worn out, with debility figured as a way of life. In another memorable phrase, Berlant describes such a scenario as slow death that occurs not as a crisis, still less a catastrophe, but within 'a zone of temporality ... of ongoingness, getting by, and living on, where the structural inequalities are dispersed, the pacing of their experience intermittent, often in phenomena not prone to capture by a consciousness organized by archives of memorable impact' (Berlant, 2007, p. 759). There may be recognisable processes of chronic ill-health, poverty and bodily dysfunction at work, but these contribute to the sense that debility is more of an enveloping context than something with a self-evident and singular cause that can be directly countered by individual or even collective action. It constitutes life as intrinsically precarious, as always vulnerable, if not to present deterioration then always in relation to imminent pathology, what Puar, appropriating Sarah Jain's term in relation to cancer (Jain, 2007), calls 'living in prognosis' (Puar, 2009) where the prognosis is never one of getting better, and yet perversely offers some hope of living on. For many people living with disabilities, as with cancer, the precarity that they experience may reflect present or intermittent illness, pain, depression and trauma, but just as likely they 
will consider themselves - once the materiality of anomalous embodiment is discounted - in good or at least ordinary health and not in need of biomedical intervention. Nonetheless, in the absence of sociopolitical infrastructures, in the time of austerity in particular, that would sustain vitality, that latter group is no less defined by precarity. As Judith Butler notes, 'precarity is indissociable from that dimension of politics that addresses the organization and protection of bodily needs. Precarity exposes our sociality, the fragile and necessary dimensions of our interdependency' (Puar et al., 2012, p. 170). One cannot disagree, but neo-liberalism disdains sociality and promotes a biopolitics that is ostensibly a matter of individual responsibility centred on personal freedom and choice. Regardless of the global economic downturn, the State in most westernised countries has withdrawn many crucial services and recast the maintenance of well-being as an issue concerning the competency of individual bodies and groups. ${ }^{4}$ There is nothing, I think, peculiar to neo-liberalism in slow death itself_capitalism has always drained the body of its vitality_but what makes the term fizz with significance is the way in which the specific traits of neoliberal capital are invested - and successfully so-in recuperating profit even in the face of inexorable deterioration.

This coextensive link between political and economic utility and debility is further mobilised, then, by the distinctively neo-liberal interface between the always already debilitated individual and the organisation of capital. Where the stress is relentlessly on the responsibility of each of us to maximise our own capacities through self-management rather than collective social care (Rose, 1996), the illusion of atomistic sovereign subjectivity reappears-and perhaps it never left us in the global North - as the guarantee that our individual choices will make a difference. Indeed, to resist the drive to autonomous choice or to fail to exercise it is to fall outside the norms of neo-liberal society, to become socially marginalised. ${ }^{5}$ The promise for the generality is that through personal strategies of body management, debility can be held at bay-for disavowal is part of the neoliberal process-or even overcome. It is a promise of not only living on but getting better. It is ironic that in recent years, and certainly overlapping with the onset of austerity measures in Europe and the United States, the pursuit of happiness as a wholly individualised experience has become such a prominent message (Ahmed, 2010). Well-being, in the empirical rather ontological sense, has become synonymous with happiness, a goal for the neo-liberal individual to pursue, whatever her starting point. As Kingfisher puts it:

Neoliberalism ... claims, in utopic fashion, that if markets are freed from state intervention and if individuals are accordingly liberated to be their naturally autonomous and entrepreneurial selves, the result will be a healthy economy producing a properly functioning society comprised of happy, self-fulfilled individuals. (Kingfisher, 2013, np)

The productive ruse is that as long as happiness remains a phantasm, just out of reach-which in the context of debility and slow death is almost inevitable - then the interminable quest for it can yield profit. In short we become self-centred entrepreneurs in search of the good life, consumers of all the myriad aids that putatively will enhance or recover our capaciousness. Where Stiker (1999) has uncovered the history of rehabilitation in terms of maximising the capacity for productive work, the neo-liberal twist introduces

\footnotetext{
${ }^{4}$ In their discussion of the impact of UK austerity measures on disability since the emergency austerity budget of 2010 , Goodley et al. (2014) cite the 2012 Disability in Austerity Study undertaken by Claudia Wood for Demos. There it was estimated that the household income of each family showed losses of $£ 2,000-3,000$ over the course of the eurrentparliament (which was elected in 2010), with disabled people losing $\mathrm{f} 9$ billion in welfare support and one-third losing their Disability Living Allowance.

${ }^{5}$ See Kolárová (2015 fortheoming) for a thought-provoking analysis of neoliberal choice in the context of the push for the rights of elderly, ill or disabled people to choose death.
} 
capacitation as a matter of attaining happiness and well-being through the acquisition of material goods (Fritsch, 2013). ${ }^{6}$ The expectation of getting better, of achieving the good life, of escaping slow death, comes at a literal cost. Those unable or unwilling to pay it are further marked as failures, lacking in moral endeavour, bad citizens, or in the case of people who necessarily rely on welfare support, as scroungers, and here race and class dimensions are always covertly evoked. What can only be called the demonisation of disabled people who do not show exceptional self-reliance has become, in the United Kingdom at least, widespread and even acceptable (Edwards and Imrie, 2008; Bambra and Smith, 2010).

I am not suggesting that all those more or less willingly engaged in the cycle of consumption and debility are simply dupes - indeed many are driven to desperation in full awareness of the callous disregard with which their lives are valued-but that the whole operation is shrouded in seductive discourses of choice, freedom, self-reliance, opportunity and fulfilment. These are powerful referents whose putative promise encapsulates what every citizen is encouraged to strive for, but they have perhaps particular resonance for people with disabilities who may have experienced a lifelong denial of just such attributes. As Berlant ( $2011 a, b)$ indicates - although concern with disability is not central to her thesis-this is at heart a cruel optimism that draws on hope but delivers very little. Under neoliberalism, living on is merged with getting better such that the aspirants of upward mobility are compelled to become consumers regardless of the risk of disappointment and debt. Disabled people are enjoined to purchase the latest aids and therapies, to employ personal assistants, to liberate their sexuality through the use of self-help manuals ${ }^{7}$ - to join the category of those 'who scrub up nice'by securing an income through waged work or entrepreneurial activity. As Fritsch (2013, p. 143) notes, 'Neoliberalism ... orients and capacitates those disabled who can afford to be included. Disability is privatized, individualized, entangled in deregulation, and profoundly affected by austerity measures'. The older trope of the heroic supercrip is replaced by that of the able-disabled that remains inspirational but appears to exclude no one.

The reach of neo-liberalism is ubiquitous, but as Fritsch indicates there are, nonetheless, divisive limitations around who can actually maintain even the illusion of getting better. Debility may be the universal default under the conditions of contemporary capitalism, but the slow death to which it assigns individuals and populations is unevenly distributed. The danger for disability scholars is to forget that questions of gender, ethnicity, nationality, age, health and many more are never absent and the elimination of differences in the liberalist imaginary is never accomplished. Some commentators like Mel Chen are hopeful that disability studies has expanded its methodologies 'beyond a historical grounding of the political and cultural specificity of whiteness and identity within the political-geographic West' (Chen, 2013, p. 95). Nonetheless, vigilance is needed insofar as neo-liberal discourses always individualise disability rather than enquire into the global systems of inequality that undoubtedly exacerbate the materiality of debility. That is not to say, however, that any body, however much it fails to realise hope, is wholly beyond the reach of neo-liberal capacitation. In a further twist, Jasbir Puar's analysis of the profitability of slow death

\footnotetext{
${ }^{6}$ Fritsch (2013) traces the trajectory of wheelchair design-the marker of disability par excellence-from the passivity of early cumbersome models operated by an aide, through lightweight designs that enabled user operation, to contemporary motorised and super-lightweight models that are entirely within the control of the disabled person herself. Enhanced freedom is, of course, marked by sharply increased prices that not only generate profit for manufacturers but create a split between those able to afford the promise of rehabilitation and those who remain further immured in slow death.

${ }^{7}$ See Matthew Sothern (2007) for a queer critique of such neo-liberal ploys.
} 
in 'Prognosis time' uncovers the added utility of data extraction that is unconcerned with degrees of debility. She writes:

If the value of a body is increasingly sought not only in its capacity to labor but in the information that it yields-and if there is no such thing as excess, or excess info, if all information is eventually used or is at least seen as having imminent utility - we might ask whether this is truly a revaluing of otherwise worthless bodies left for dying. ... Are all bodies really available for rehabilitation? (Puar, 2009, p. 164)

In short, the living on of some bodies occurs only as the material person is erased.

The general paradox, then, is that for all the stress on inclusion and the imperative to self-realisation, the actual effect of neoliberal measures may have just the opposite effect in creating new forms of differentiation. In the United Kingdom, the cross-party think tank Demos lists the effects on disabled people of the Government's austerity programme as including '(a)n ever-diminishing level of civic and social engagement' with households 'becoming socially more isolated, and reducing the amount of activities they engage in-from essentials such as work and medical appointments to "luxuries" such as volunteering and training' (Wood, 2012, p. 14). This clearly runs counter to the Government's declared vision of stronger and more active communities, but not, I would suggest, to the realisation of neo-liberalism in slow death. Despite the dominant emphasis within disability politics of the last couple of decades in promoting the social model of disability, which has been successful to the extent that it is seen to underpin both the UK Disability Discrimination Act (1995) and the US Americans with Disabilities Act (1990), the individualised politics and policies of neo-liberalism are directed not at any radical transformation of the structural exclusions of mainstream ableist society but towards a focus on re-capacitating the individual, as though that were ever possible without taking the wider socio-political context into account. In the United Kingdom, for example, the push to increase the productivity and financial contribution of disabled people to their own support needs has resulted in a blanket re-examination of every individual's fitness to work. For the majority this has taken the form of being subjected to a Work Capability Assessment (WCA), a process that has become notorious for its arbitrary decision making and patent lack of justice. Over three-quarters of those undergoing examination-which seems to be done entirely without medical or social contextualisation - are declared capable of some form of paid employment regardless of the evident severity of their disabling conditions, and therefore are ineligible for certain benefits. To date, around 50 per cent of those denied such financial supports have appealed, with around 40 per cent of the appeals being upheld, leading to full or partial restoration of the status quo. The effect on the lives of groups already vulnerable to state interventions designed to drive down expenditure in times of austerity is hard to measure, but the popular UK tabloid The Daily Mirror-against the grain of widespread media disaffection with welfare claimants - has been sufficiently concerned to do some research.

We've used the Freedom of Information Act to discover that, between January and August last year, 1,100 claimants died after they were put in the 'work-related activity group'.

This group — which accounted for 21 per cent of all claimants at the last count - get a lower rate of benefit for one year and are expected to go out and find work. This compares to 5,300 deaths of people who were put in the 'support group'which accounts for 22 per cent of claimants_-for the most unwell, who get the full, no-strings benefit of up to $\mathrm{f} 99.85 \mathrm{a}$ week. 
We don't know how many people died after being found "fit to work", the third group, as that information was "not available'. But we have also found that 1,600 people died before their assessment had been completed. (Sommerlad, $2012)^{8}$

Similar figures are echoed by disability activist Cross (2013), who highlights one of the most pernicious outcomes of the WCA in her claim that in 2011 there were at least thirty suicides resulting from punitive assessments. The latest official figures released by the Department of Work and Pensions in late 2014 point to sixty more benefit-related suicides in the subsequent 2 years (Pring, 2014). Sometimes the death is not so slow.

Shocking though such reports might appear, it remains the case that disabled people have borne the brunt not only of cumulative welfare cuts, but also of a marked emergence of negative representations and feelings directed against them. Where the terms shirkers and scroungers were often previously deployed unreflectively against the unemployed, people with disabilities are now at the forefront of angry verbal, and increasingly physical, attacks. In a recent article, Slater (2012) analyses the case of Jody McIntyre, a young disability activist assaulted by the police during a demonstration against cuts in youth education. Alongside many expressions of an unthinking sympathy that is routinely evoked for disabled people as supposedly deserving and in need of special care, many highly hostile comments were posted in response to the YouTube video of Mclntyre being dragged from his wheelchair by a police officer. As Slater points out, in neither case was any awareness shown of the wider context of McIntyre's opposition to particular cuts in state funding. In keeping with the neo-liberal mantra of the coalition government that 'we are all in this together', McIntyre's case was thoroughly depoliticised and individualised. Many of my examples, as with the Mclntyre case, relate to the situation of disabled people in the United Kingdom, but I do not want to suggest that the same phenomena are not happening to other groups and in other places (Coulter, 2009; Soldatic and Meekosha, 2012). Moreover, whether the proximate marker of difference is poverty, illhealth, race, ageing, immigrant status or unemployment, there is a broad consensus that the negative effect on women is over-determined, ${ }^{9}$ though few politicians have been brave enough to point out the patent discrimination involved. The same mechanism that enables verbal abuse is, then, also productive of what is widely referred to as hate crime, although that term is not recognised as such in law in the context of disability. Nonetheless, it is a clearly growing phenomenon, albeit one that elicits surprisingly little commentary outside of academia and the disability community (Briant et al., 2013). The urgent issue is to understand why a heightened antipathy directed against specific groups has emerged in such a manner. Could it be that debility as a worldwide experience can only be endured or disregarded as such if it is firmly associated with existing and devalued embodied differences?

My argument is that the growing incidence of such confrontational events is strongly related to a subconscious, but highly motivating, awareness in the global North that, particularly after the economic crisis of 2008, everyone is living through a period of heightened precarity. The analysis I have developed elsewhere of the operation of abjection in relation to embodied vulnerability (Shildrick, 2002, 2009)

\footnotetext{
${ }^{8}$ The Mirror report antedated the celebration of disability occasioned by the London Paralympics by just a few months, but the point is that that brief moment changed nothing in wider public attitudes. It is only the able-disabled who can count as valued citizens. The bitter irony of the contrasting perspectives on disability is that the contractor, ATOS, who operationalised the Work Capability Assessment was also the major sponsor of the Paralympics. After widespread criticism, they have withdrawn from the contract, but the WCA continues.

${ }^{9}$ I will not develop this line of thought here as I am sure other contributors to the Feminist Review special issue will do so.
} 
indicates how the relatively hopeful mainstream may feed on the anxiety occasioned by widespread economic insecurity to create the perfect storm of antagonism towards people with disabilities. The contemporary moment of socio-political shock in the face of imposed austerities and a generation that knows it is not getting better, that implicitly understands debility as the new norm, demands its scapegoats. What is emerging, I think, is a new psycho-political imaginary in which entrenched intolerance of visible differences finds new expression in demonising those who-by a brutal sleight of hand that obfuscates the actual powerlessness of such groupings — can be held responsible for both financial and existential uncertainty. The disavowal of self-centred anxiety in the move to resentment and mistrust of others surely fulfils the Kristevan understanding of abjection as a process that appears to offer provisional relief but arrives at no resolution. If an external threat can be identified-the irrational image, say, of disabled people wiltfully using impairments to gain access to scarce resources - then the potential dread of one's own powerlessness in the face of debility might be averted. If only they could be mastered and put in their place, then all would be well. ${ }^{10}$ The imposition of rigid distinctions between states of deserving and undeserving need has long been a tactic of exploitative capitalism, but it gains traction in the contemporary scene, rather than invokes revolt, precisely because it plays into widely shared, but disavowed, fears and anxieties that living on does not equate with getting better. And it is important to remember that, though it operates at the psychic level, the process of abjection that I describe is not simply a matter of a personal fantasy response to the failure to secure the good life, but the outcome of a highly political structural shift in how late capitalism functions. People with disabilities have good reason to abhor the assumption of a special frailty deserving of paternalistic care, but the return to prior modes of representation that evoke fear and avoidance (Shildrick, 2002, 2009) may be even more damaging. The difference between the present and the past, however, is the operation of a very different driver of antipathy: that of putative competition. While neo-liberalism imposes debility on us all, the logic of communality is, nevertheless, suspended.

The issue for critical thinkers, then, is that although the concept of debility works in a positive way to disrupt the binary distinction between disabled and non-disabled embodiment, it may do so at the cost of failing to distinguish what is unique to disability. The concern voiced by disability theorist David Mitchell (2015) that the nonconventional analysis of debility posits a problematic 'we', by suggesting a commonality that covers over the material specifics of each person's experience, deserves attention, but it seems to me to have more traction in scholars such as Butler and Berlant who are not writing primarily about disability. Certainly Puar, who has been the major proponent of debility as an analytic tool, carefully avoids any such trap, while the former scholars-see especially the round table on precarity (Puar et al., 2012) —are careful to clearly mark the differential distribution of that quasi-universal state of always falling short of the good life. When Butler (2006) first introduced the term precarious, which I understand in part as a synonym of the vulnerability of the human condition (Shildrick, 2002), she stressed from the beginning its shared nature and embeddedness in a locus of interdependencies. Yet though all lives are deeply touched by and dependent on others, vulnerability and its effects are made visible and experienced in very different degrees. As she insists, 'our social vulnerability and exposure ... is always given some political form' (Puar et al., 2012, p. 169) and the conditions for continued life are unequally distributed. I am not claiming that precarity and debility are entirely coincident-the degree of openness and

\footnotetext{
${ }^{10}$ As I write, the UK Conservative party, the dominant group in the coalition government, have just announced further swingeing, but broadly populist, cuts to the welfare budget.
} 
attendant risk are arguably very different-but that both demand a focus on wider structural elements, without losing sight of particularities. It matters to break with the individualisation promoted by neoliberalism, to eschew the seductive call to self-sovereignty, and yet still retain an acute sensibility towards how debility is phenomenologically experienced. The urge for upward mobility, or at least to fully realise one's capabilities, is directed at all in both the global North and South, but it is clear to me that some people, at least during their own lives-Puar (2009), remember, alerts us to the utility of posthumous data extraction-almost entirely elude neo-liberal capacitation, but not its affects. What I am referring to here is not usually a self-evidently positive refusal to participate, but more likely a troubled position in which hope and expectation are never fully extinguished, but are brutally and overtly frustrated.

One response to such a scenario is apparent in Butler's most recent work, where she speaks of vulnerability 'as a form of activism, or as that which is in some sense mobilized in forms of resistance' (Butler, 2014, p. 99), and insists that it should not be equated with injurability alone. A similar and perhaps more radical reimagining, which is associated with cripqueer theory in particular, has been to celebrate what Halberstam (2011) calls the queer art of failure, whereby failure 'imagines other goals for life, for love, for art, and for being' (p. 88). In place of neo-liberal entreaties to optimism, hope, happiness and success, the willing embrace of falling short of normative expectations acts as a method of survival in which debility might no longer carry a negative charge. The more usual disability literature on failure routinely deplores the label and recognises its discursive nature, but fails to contest the binary thinking behind it, thus feeding straight back into narratives of rehabilitation. In contrast, a queer perspective challenges the whole economy of winners and losers and recognises that in our neo-liberal times of false hope and optimism, and the oppressive imposition of self-responsibilisation, the notion of failure can begin to prise apart supposed political veracities. As Kolářová puts it:

Cripness is already rich with failure; cripness is infused with negativity that sustains. The crip negativity I plead for is a critical strategy rupturing ideologies of cure, rehabilitation and overcoming, ideologies that inflict hurt and violence (not only) on crips (Kolářová, 2014). ${ }^{11}$

The point, of course, is to shape alternative forms of communality, not to accept debility as an isolated occurrence. There is much to recommend in such a reconfiguration and it merits serious consideration, but it does come up against the uncomfortable reality that sometimes failure cannot be reclaimed. It may help to reject the idea that my cancerous body is not my own fault but I would willingly accept effective pain relief and the medicalisation that goes with it. Not all hurt is ideological. In consequence, my own preference-and it remains exploratory - is to travel briefly a different line of flight that is more influenced by Deleuze, whose understanding of both joy and endurance enables the thought of debility as both material and discursive.

The turn to Deleuze, the philosopher of difference, is motivated precisely by his refusal to become enmeshed in the politics of the personal, whilst never forgetting the materiality of what makes lives liveable. At the very centre of his philosophy is a decisive break with the notion of an atomistic subjectthe sovereign subject of modernity—-who exercises freedom, choice, rationality and individual agency and

\footnotetext{
${ }^{11}$ That perspective is far from mainstream. As cripqueer theorist Kafer (2013, p. 102) sardonically writes, 'Whenever I tell people I have been working on a book about the role of disability in imagined futures, they almost always assume I'm writing about science fiction'.
} 
who equally must experience alone pain, suffering and dissolution. In place of such static 'being', Deleuze proposes a state of becoming in which any provisional subject is always in a process of unravelling (Deleuze and Guattari, 1984, 1987), an unravelling that may be read as a form of vulnerability. In itself, the process is impersonal, neither good nor bad, encompassing all that may happen and continually transforming it. Every one of us is entangled in what Deleuze calls assemblages, those multiple and shifting webs of interconnections, both organic and inorganic, that constitute life itself. Perhaps surprisingly, Butler has not just Donna Haraway but Deleuze too in mind when she asserts, "we cannot understand bodily vulnerability outside of this conception of its constitutive relations to other humans, living processes, and inorganic conditions and vehicles for living' (Butler, 2014, p. 103), and later, 'bodies are not self-enclosed kinds of entities' (ibid., p. 116). ${ }^{12}$ There is no internal structure or necessity to the assemblage; it is just a provisional cluster of contingent relations that come together, evolve and change over time, before equally unpredictably breaking apart. In taking account of multiple heterogeneous orders, Deleuzian thought is concerned with the effects of mutual interactions, not with privileging any one component above others. It is not that normative elements play no part, but that they no longer occupy a hierarchical position of dominance as they would in conventionally structured discourse. Instead of the pre-existing meaning of an element determining the nature of its possible connections, in an assemblage, the dynamic is reversed with the interconnections themselves generating meaning. While the theory may appear abstract in its conception, nevertheless it produces, as Deleuze and Guattari see it, wholly material and political effects. The concern is not with the ontology of bodies, but with what they are capable of. When a body is produced as debilitated, it does not stand alone, and nor do the conditions of production remain static. Critical disability theory has only recently begun to appreciate the potentialities of the Deleuzian approach, ${ }^{13}$ but assemblages are highly significant in enabling us to think differently about embodiment in ways that reclaim devalued bodies that have been declared incapable (Shildrick, 2009, 2015 , fortheoming). ${ }^{14}$

For Deleuze, in any case, what is at stake is not the possession or lack of functional efficacy, or the expectation of a successful life, but what Braidotti (2006, p. 137) has called sustainability: 'the very possibility of the future, of duration, of continuity'. What that indicates for both is that beyond the personal life course lies an incorporeal impersonal vitalist force towards which my own experiences merely contribute. Yet temporally I am not insignificant; and my own sustainability matters, even as it encompasses not simply pleasures but the endurance of breakdown, distress and suffering. What makes living on in terms of personal existence a positive force-even in the mode of slow death-is the power to affirm life, to continue to enhance one's potentials. No individual can determine her own life course, but she must nonetheless strive to be the 'quasi-cause' of what occurs. In contradistinction to modernist societies that are intolerant of difference and seek to regulate what is deemed appropriate to any given body, the Deleuzian approach advocates pushing to the limits of what is possible, embracing uncertainty and radical change, and sustaining becoming, however that plays out. Although an individual may face

\footnotetext{
${ }^{12}$ Compare Deleuze and Guattari (1987, p. 284): 'we know nothing about a body until we know what it can do, in other words, what its affects are, and how they can or cannot enter into composition with other affects, with the affects of another body'.

${ }^{13}$ As well as my own work, see, for example, Goodley (2007), Gibson et al. (2012) and Feely (2014).

${ }^{14}$ Erevelles (2014), again, raises a cogent question: 'What does it mean to come to terms with the transgressive vagaries of ... assemblage - precarious/partial/body-without-organs/liminal/affective/molecular-within political economic contexts imbricated in colonial/neocolonial practices of unrelenting social, economic, and militarized violence?' (np). Similar, though more local, concerns are addressed in a joint paper by Ecclestone and Goodley (2014), who outline but do not resolve their differences.
} 
misfortunate in the here and now, she should avoid ressentiment and willingly embrace all that befalls her. For Deleuze (1990, p. 149), what matters is 'not to be unworthy of what happens to us'. For all that the lives of us all are formed in interconnection with an array of others, that is no pass on personal responsibility. It might even be that those who could be classed as failing are at the forefront of affirming life. As Braidotti (2006, p. 130) argues, and she refers explicitly to alcoholism and drug addiction, the vulnerable ones are most able to contest the deadening sameness that constitutes normativity; while Deleuze (1990), reflecting on bodily breakdown, wonders whether it is 'only by means of the crack and at its edges thought occurs, that anything that is good and great in humanity enters and exits through it, in people ready to destroy themselves' (p. 160). The good life for Deleuze, then, is one that sustains itself in conditions of adversity, by always opening up to new possibilities of productive alternatives. The other side of that approach, unsurprisingly, is that should the conditions of individual existence block the realisation of joyous endurance, then life-in its enveloping vitalist sense-may also be affirmed through death, including suicide. Flourishing does not simply refer to the conditions of living but has a wider meaning in which the event of death enables life to recompose under new relations of sustainability.

Is then 'living on; not getting better' the only way of understanding debility? My somewhat cautious answer is beyond that gloomy option, there are openings in a queer futurity that propose a different kind of flourishing. It is decidedly not life as we know it, even less a neo-liberal utopia of fully realised capacitation, but it does speak to the hope that everyone, regardless of their material circumstances and forms of embodiment, may be part of an unending vitalist process of transformation. I am wary of positing what might amount to no more than an academic form of cruel optimism, but that is surely to retreat once again to an individually centred view of what matters. To return to my opening questions, then, I think we can concede that few if any bodies-none, if Puar follows the logic of her own analysis-escape the tentacles of neoliberalism, though the consequent immersion in debility and slow death is experiencedand again personally - in very different degrees. My desire not to lose the specificity of disability in the more general term survives the test, and the ambivalence of where precisely distinctions matter and where they do not is productive rather than disturbing. Deleuze often seems a step too far for feminist, disability and queer theory alike, but here he offers an intriguing alternative, a reimagination of the conditions of life that allow us all to flourish. Let us, as Braidotti has so effectively done before, seize the opportunity and run off in new feminist directions.

\section{references}

Ahmed, S., 2010. The Promise of Happiness. Durham, NC: Duke University Press.

Bambra, C. and Smith, K., 2010. No longer deserving? Sickness benefit reform and the politics of ill health. Critical Public Health, 20(1), pp. 71-83.

Berlant, L., 2011a. Slow death (sovereignty, obesity, lateral agency). Critical Inquiry, 33, pp. 754-780.

Berlant, 2011b. Cruel Optimism. Durham, NC: Duke University Press.

Berl tt, L. and Prosser, J., 2011. Life writing and intimate publics: a conversation with Lauren Berlant. Biography, 34(1), pp. 180-187.

Braidotti, R., 2006. Transpositions: On Nomadic Ethics. Cambridge: Polity Press.

Briant, $\boldsymbol{\varepsilon}$., Watson, N. and Philo, G., 2013. Reporting disability in the age of austerity: the changing face of media representation of disability and disabled people in the United Kingdom and the creation of new 'folk devils'. Disability \& Society, 28(6), pp. 847-889. 
Butler, J., 2006. Precarious Life: The Power of Mourning and Violence. London: Verso.

Butler, J., 2014. Bodily vulnerability, coalitions, and street politics. Critical Studies, 37, pp. 99-119.

Cross, M., 2013. Demonised, impoverished and now forced into isolation: the fate of disabled people under austerity. Disability \& Society, 28(5), pp. 719-723.

Deleuze, G. and Guattari, F., 1984. Anti-Oedipus: Capitalism and Schizophrenia, Tr. R. Hurley London: Athlone Press.

Deleuze, G.2 1987. A Thousand Plateaus: Capitalism and Schizophrenia, Tr. B. Massumi Minneapolis, MN: Minnesota University Press.

Deleuze, G., 1990. The Logic of Sense, Tr. M. Lester London: Athlone Press.

Ecclestone, K. and Goodley, D., 2014. Political and educational springboard or straitjacket? Theorising post/human subjects in an age of vulnerability. Discourse: Studies in the Cultural Politics of Education. Available at: http://dx.doi.org/10.1080/ 01596306.2014 .927112 [last accessed 18 January 2015].

Edison, L.T. and Notkin, D., 2010. Temporarily able-bodied: Useful but not always true. Forward (Feminists with Disabilities), 3 February. Available at: http://disabledfeminists.com/2010/02/03/guest-post-temporarily-able-bodied-useful-but-notalways-true/ [last accessed 11 September 2014].

Edwards, C. and Imrie, R., 2008. Disability and the implications of the wellbeing agenda: some reflections from the United Kingdom. Journal of Social Policy, 37(3), pp. 337-355.

Erevelles, N., 2014. Thinking with disability studies. Disability Studies Quarterly, 34(2). Available at: http://dsq-sds.org/article/ view/4248/3587 [last accessed 15 April 2015].

Feely, M., 2014. Sexuality and Intellectual Disability: A Critical Cartography of a Community-Based Service. Belfast: Queen's University Belfast.

Ferguson, I., 2007. Neoliberalism, happiness and well-being. International Socialism, 117, pp. 1-15.

Fritsch, K., 2013. The neoliberal circulation of affects: happiness, accessibility and the capacitation of disability as wheelchair. Health, Culture and Society, 5(1), pp. 135-149.

Garthwaite, K., 2011. 'The language of shirkers and scroungers?' Talking about illness, disability and coalition welfare reform. Disability \& Society, 26(3), pp. 369-372.

Gibson, B., Carnevale, F. and King, G., 2012. 'This is my way': reimagining disability, in/dependence and interconnectedness of persons and assistive technologies. Disability \& Rehabilitation, 34(22), pp. 1894-1899.

Goodley, D., 2007. Becoming rhizomatic parents: Deleuze, Guattari and disabled babies. Disability \& Society, 22(2), pp. 145-160.

Goodley, D., Lawthom, R. and Runswick-Cole, K., 2014. Dis/ability and austerity: beyond work and slow death. Disability \& Society, 29(6), pp. 980-984.

Halberstam, J.J., 2011. The Queer Art of Failure. Durham, NC, London.

Jain, S.L., 2007. Living in prognosis: toward an elegiac politics. Representations, 98(Spring), pp. 77-92.

Kafer, A., 2013. Accessible Futures: Feminist, Queer, Crip. Bloomington and Indianapolis, IN: Indiana University Press.

Kingfisher, C., 2013. Happiness: notes on history, culture and governance. Health, Culture and Society, 5(1), pp. 67-82.

Kolářová, K., 2014. The inarticulate post-socialist crip: on the cruel optimism of neoliberal transformations in the Czech Republic. Journal of Literary and Cultural Disability Studies, 8(3), pp. 257-274.

Kolárová, K., 2015, fortheoming. Death by choice, life by privilege: bio-political circuits of vitality and debility in the times of empire. In S. Tremain, ed. Foucault and the Government of Disability, 2nd Edition, Ann Arbor, MI: University of Michigan Press.

McRuer, R. and Johnson, M.L., 2014. Proliferating cripistemologies. A virtual roundtable. Journal of Literary \& Cultural Disability Studies, 8(2), pp. 149-169.

Mitchell, D., 2014. Gay pasts and disability future(s) tense. Journal of Literary \& Cultural Disability Studies, 8(1), pp. 1-16.

Mitchell, D. and Snyder, S., 2015. The Biopolitics of Disability: Neoliberalism, Ablenationalism, and Peripheral Embodiment. Ann Arbour, MI: University of Michigan Press.

Overboe, James, 1999. 'Difference in itself': validating disabled people's lived experience. Body \& Society, 5(4), pp. 17-29.

Pring, J., 2014. DWP admits investigating 60 benefit-related deaths since 2012. Disability News Service, 14 November. Available at: http://disabilitynewsservice.com/2014/11/dwp-admits-investigating-60-benefit-related-deaths-since-2012/ [last accessed 18 January 2015]. 
Puar, J., 2009. Prognosis time: towards a geopolitics of affect, debility, and capacity. Women \& Performance: a journal of feminist theory, 19(2), pp. 161-173.

Puar, J., 2012. Coda: the cost of getting better: suicide, sensation, switchpoints. GLQ, 18(1), pp. 149-158.

Puar, J., Berlant, L., Butler, J., Cvejic, B., Lorey, I. and Vujanovic, A., 2012. Precarity talk. TDR: The Drama Review, 56(4), pp. 163-177.

Rose, N., 1996. Inventing Our Selves: Psychology, Power, and Personhood. Cambridge: Cambridge University Press.

Slater, J., 2012. Stepping outside normative neoliberal discourse: youth and disability meet-the case of Jody McIntyre. Disability and Society, 27(5), pp. 723-727.

Soldatic, K. and Grech, S., 2014. Transnationalising disability studies: Rights, justice and impairment. Disability Studies Quarterly, 34(2). Available at: http://dsq-sds.org/article/view/4249 [last accessed 9 June 2015].

Soldatic, K. and Meekosha, H., 2012. The place of disgust: Disability, class and gender in spaces of workfare. Societies, 2(3), pp. 139-156. Available at: http://www.mdpi.com/2075-4698/2/3/139 [last accessed 22 April 2014].

Sommerlad, N., 2012. 32 die a week after failing test for new incapacity benefit. Daily Mirror, 4 April. Available at: http://blogs .mirror.co.uk/investigations/2012/04/32-die-a-week-after-failing-in.html [last accessed 15 September 2014].

Sothern, M., 2007. You could truly be yourself if you just weren't you: sexuality, disabled body space, and the (neo) liberal politics of self-help. Environment and Planning D: Society and Space, 25(1), pp. 144-159.

Spivak, G.C., 1989. 'In a word'. Interview with Ellen Rooney. Differences, 1(2), pp. 124-156.

Stiker, H.-J., 1999. A History of Disability, Tr. W. Sayers Ann Arbor, MI: University of Michigan Press.

Titchkosky, T., 2003. Governing embodiment: technologies of constituting citizens with disabilities. Canadian Journal of Sociology/Cahiers canadiens de sociologie, 28(4), pp. 517-542.

Wood, C., 2012. Destination Unknown: Summer 2012. London: Demos.

doi:10.1057/fr.2015.22 